\title{
Investigation of Competitive Advantage of the Dairy Industry Cluster: The Case of Rwanda
}

\author{
Antoine Matemane Mahirwe, Long Wei \\ School of Economics, Wuhan University of Technology, Wuhan, China \\ Email: hirwa77@hotmail.com
}

How to cite this paper: Mahirwe, A.M. and Wei, L. (2018) Investigation of Competitive Advantage of the Dairy Industry Cluster: The Case of Rwanda. American Journal of Industrial and Business Management, 8, 1358-1388.

https://doi.org/10.4236/ajibm.2018.85092

Received: March 31, 2018

Accepted: May 27, 2018

Published: May 30, 2018

Copyright $\odot 2018$ by authors and Scientific Research Publishing Inc. This work is licensed under the Creative Commons Attribution International License (CC BY 4.0).

http://creativecommons.org/licenses/by/4.0/

\begin{abstract}
This paper explores the dairy industry cluster in Rwanda and its competitive advantage basing on the Porter's diamond model. Additionally, this study identifies other factors critical to the competitiveness of the dairy industry cluster in Rwanda and includes them to the diamond model to create a multiple diamond model. This study argues that the direction taken to increase milk supply in Rwanda by increasing the number of cattle farmers through the government program known as "One cow per poor family" is not suitable in that it exerts more pressure on already scarce resources such as land. In fact, this study suggests that given the challenges facing the dairy industry, more emphasis should be put on improving efficiency and increasing productivity in the value chain. This study proposes the multiple-diamond model which extends Porter's Diamond model to include other factors central to the competitiveness of the dairy industry cluster in Rwanda. To test the effect of the proposed multiple-diamond determinants, ARDL test was run. The findings confirmed the effect of trade openness on the dairy cluster industry competitiveness. Development assistance and milk cattle were found to have a negative and significant effect on the dairy cluster industry competitiveness while FDI inflow and market sophistication were found to have non-significant effect. The study concludes by providing recommendations for future studies in this field.
\end{abstract}

\section{Keywords}

Dairy Cluster, Competitiveness, Domestic Diamond, Multiple Diamonds

\section{Dairy Cattle: A Deep-Rooted Love Affair in Rwanda}

Agriculture remains the main economic activity in Rwanda with $70 \%$ of the population engaged in the sector, and employs about $72 \%$ of the working popu- 
lation [1]. Agriculture is vital for Rwanda's growth and reduction of poverty, as the backbone of the economy, it accounts for 39 percent of gross domestic product (GDP), 80 percent of employment, 63 percent of foreign exchange earnings, and 90 percent of the country's food needs [2]. However, this sector is faced with several challenges ranging from insufficient land, water shortage, lack of public and private capacity, and limited commercialization constrained by poor access to output and financial markets. Dairy plays an important role in both rural and national economies with $8.8 \%$ contribution to the national gross domestic product [3]. The dairy industry is the largest segment of the livestock sector in Rwanda, which accounts for $10.5 \%$ of agricultural GDP and is the fastest growing sub-sector within agriculture [4]. Livestock, mainly dairy cattle, has historically been an essential part of the production systems in Rwanda [5]. The activity of cattle farming is deeply rooted in the Rwandan culture, this is reflected in local taboos, sung poetries, ritual dances, friendship ties and gratitude gestures [5] [6]; in fact, cattle farming is still linked to economic status of households in Rwanda [3]. For centuries, Rwandans have raised cows for their milk, skin, and meat; therefore, it was regarded as valuable to the well-being of families.

Cattle farming and related products especially milk have also played a dividing role in the history of Rwanda [3], whereby economic class-later taken as ethnic groups-was determined basing on cattle head owned by house old. For that reason, the government of Rwanda finds it imperative to ensure that cattle farming is practiced by any willing citizen so that it could play a rather constructive role to the socio-economic welfare of the population.

To achieve its objective of becoming a middle-income country as set out in its 2020 Vision, in 2013, the government of Rwanda has put in place a National Dairy Strategy which would help to tackle challenges which are facing the dairy sector such as access to finance, infrastructure, inadequate and shortage of skills, insufficient demand, low quality, high production cost, and less competitive vis-à-vis that of other regional players such as in Kenya and Uganda [7]. Due to its strategic importance in national economy, the government has made tremendous investment to increase efficiency, improve productivity and boost entrepreneurship in the dairy industry [6] [8] [9]. Investment by the government of Rwanda, international development agencies, and the private sector has led to improvement along the dairy value chain. Different initiatives such as the "one cow per poor family" program have made a significant contribution to the increase of cattle head count, the number of participating farmers and dairy production [6] [8]. Moreover, the construction of Milk Collection Centers (MCC) across the country led to rapid development of the dairy sector by increasing efficiency in the value chain [10]. There has been significant increase of cattle from the pre-1994 level of 600,000 heads to now 1,349,792, which include 615,631 (45\%) local breeds, 439,414 (33\%) dairy cross-breeds, and 294,747 (22\%) dairy pure breeds [4]. However, despite all the above, the competitiveness of the dairy 
industry of Rwanda still lags behind that of most of other east African countries such as Kenya, Tanzania and Uganda. The study results by Klapwijk, Bucagu [11] indicated that the majority of people involved in farming are faced with challenges to keep either local or European breed due to the cost related to farming activities. The study conducted by Mutimura, Lussa [12] highlighted the issue of feed shortage mainly caused by limited land availability. This study also pointed out that this shortage is addressed by sourcing feed from neighboring countries. This puts in doubt the strategies being used to increase its competitiveness; there is an urgent need to properly identify the key determinants of the dairy industry's competitiveness in Rwanda and urge the government to make adjust its strategies accordingly in order to drive the competitiveness of its dairy industry which still plays an important role in its GDP growth. According to the goal set in the national dairy strategy (NDS), a competitive dairy sector should be able to provide dairy products which are affordable, available, as well as accessible to both domestic and regional consumers. Milk and dairy products are vital for the daily food security of many Rwandans due to their nutrition content, thus their affordability highly important especially for people of a low income country like Rwanda. In addition, dairy production is very important source of income for Rwandans, the majority of which lives in rural area with agricultural activities as their only reliable source of income [13].

The purpose of this study is to identify key factors which influence the competitiveness of the dairy industry. To do so, this study builds on factors available in the national diamond by selectively including other factors brought about by the country connectivity with other countries which are central to the improvement and upgrading of the national diamond.

In this regard, this study will attempt to identify the main determinants of the competitiveness of the dairy industry cluster in Rwanda by building on Porter's home-based diamond; this study will seek to reflect on the role of interaction of the domestic diamond to other nations diamonds to enhance its competitiveness by extending the diamond model to include other factors deemed crucial to the upgrading of the domestic diamond. In this regard, this study will propose a multiple diamond model. The diamond model is designed to help understand how factors specifically available in an economy affect its competitiveness and that of its industries. It also shed light on the role of the government as a catalyst in improving its global competitive position [14] [15]. However, this model cannot fully explain the competitiveness of an economy with a weak domestic diamond such as that of Rwanda [16]; thus other factors have which interact with the domestic diamond to generate its competitiveness and that of its industries must be identified. This model is relevant in this case given challenges facing the dairy industry due to limited resources in the Rwandan domestic diamond and the role that the government and other countries diamonds have to play to offset these challenges and generate competitiveness.

This study contributes to the existing literature in the following way: it is the 
first of its kind to assess the competitiveness of an industry basing on the proposed extended diamond model; to do so, this study brings in new factors such as foreign aid and human cross-border movement which have never been mentioned by previous studies which attempted to extend the diamond model. Finally, this study joins other previous studies which indicated the shortfall of the domestic diamond to fully explain the competitiveness.

The rest of this study will be structured as follows: the next section is the theoretical review, followed by Methodology and data description, followed by test results and discussion, followed by conclusion and recommendations, and the last section will highlight this study's limitation and proposes directions for future research.

\section{Theoretical Review}

\subsection{Introduction}

Porter [14], Porter [15] developed a model known as Porter's Diamond Theory of National Advantage designed to help understand the competitive advantage enjoyed by nations in certain industries groups due to specific attributes and aspects of their domestic diamond; the model also explain the intervention of the government in stimulating global competitiveness within an economy. According to Porter, particular competitive industries within a nation determine the competitive advantage of that nation. However, the existence of clusters of indigenous or "home-base" industries which are competitive and are linked together through a range of common, supporting conditions plays a crucial role in achieving competitive advantage. Porter [15] argued that the old theories of Adam Smith and David Ricardo which are based on factor endowment are not sufficient to explain competitiveness between technology advantages in the nations of today. He argued that rather than originating from natural endowments, labor pool or interest rates, the national prosperity is created [15]. According to Porter the competitive advantage of an industry originates from four different determinants of competitive advantage which are created within the home base of the nation state; this is illustrated in the Diamond model with four main determinants: 1) factor conditions, 2) demand conditions, 3) related and supporting industries, 4) firm strategy, structure and rivalry. The model also identifies two additional determinants which influence the four main determinants namely governmental policy and the role of chance events. These four determinants mutually influence each other and a change in one of them affects all other three determinants. The operational concept in Porter's model is the particular process that leads to the development of clusters. All determinants operate as a system to generate conditions that give rise to industry clustering. The diamond must be taken as a system; the effect of one determinant often depends on the state of others and weakness in any one determinant will constrain an industry's potential for advancement and upgrading. In addition, the points of the diamond are self-reinforcing; therefore, in the process of clustering, a competitive 
industry will develop and support another in a mutually reinforcing process. In a similar way, the presence of rivals in one location stimulates the development of unique pools of specialized factors. The interaction between determinants to achieve competitive advantage illustrates the emphasis of Porter's diamond on geographic proximity to facilitate the flow of information which is key to the innovativeness of firms within the cluster in order to achieve competitive advantage.

The diamond model has been used extensively in previous studies to investigate the competitiveness of particular nations and industries. To investigate the competitive advantage of apparel industry in Korea, Jin and Moon [17] based on the diamond model to identify new sources of competitive advantage factors; furthermore, the study uses the generalized double diamond model whereby the country's international activities are taken into account as source of competitiveness of the apparel industry. To investigate the competitive advantage of shadow banking, the study conducted by Riasi [18] based on the diamond model and indicated that factor conditions, chance and government do not contribute to the competitiveness of shadow banking industry whereas related and supporting industries, firm strategy, structure and rivalry, and demand conditions contribute to the competitiveness of shadow banking industry. The study by Chaabna and Wang [19] carried out an investigation and analysis of the state of e-commerce in Algeria, this study identified the nature of the barriers which hinder the growth of the country and suggested some solutions basing on the diamond model. Basing on the diamond's model, the study by Aghdaie, Seidi [20] attempted to identify obstacles of Iran's export of saffron to international market in order to maintain the country's global competitiveness in this area. The findings of this study revealed that demand conditions, related and supporting industries, firm strategy, structure and rivalry, government, and chance evnent constituted the most critical obstacles whereas factors conditions constituted no major obstacle to export of saffron. Mann and Byun [21] conducted a study to assess the competitiveness of the Indian apparel retail industry as well as its changing market conditions following retail trade liberalization, the study based on the diamond model to identify key opportunities and challenges of entering the Indian apparel retail industry.

Despite its extensive use in the literature, the diamond model was not immune to criticism; in fact, it has been highly criticized for undermining the role of FDI and country connectivity [22] [23] [24] [25] as well as overlooking the role of the human capital in the process of creating competitiveness within an economy [26] [27]. According to critics, the home-based diamond can be enhanced by a stronger diamond of a more powerful trading partner. Critics pointed out that Porter's diamond model can only be relevant when analyzing the competitiveness of a big economy [16]; it was suggested that for small open economy, consideration should also be given to the fact that a country can tap into foreign country's diamond to enhance its own diamond [28]; the role of FDI and cross-border alliance in the process of enhancing and upgrading the 
home base factors was of great significance [22] [23]. Subsequently, other models were suggested to explain the competitiveness of countries in a more comprehensive way. These include the nine factor model [26] [27], the double diamond [22] [28] [29], the double diamond model [30], and the multiple diamond [31] [32] [33]. This study argues that if considered alone, the Rwandan home-base diamond cannot have a significant explanatory power of the competitiveness in the dairy industry cluster; its connectivity to other diamonds contributes significantly to its competitiveness. This is facilitated by regional integration agreements in place, geographic proximity, free movement of goods and people and any other cross-border transactions. In this regard, this study will use the Multiple Diamond model to assess the competitiveness of the dairy industry cluster in Rwanda. This model will be based on regional integration within East African Community. East African Community (EAC) is a regional intergovernmental organization of 6 Partner States: the Republics of Burundi, Kenya, Rwanda, South Sudan, the United Republic of Tanzania, and the Republic of Uganda, headquartered in Arusha, Tanzania. EAC is home to 185 million citizens on a land area of 1.82 million square kilometers, $23 \%$ of its total population lives in urban areas [34]; its combined Gross Domestic Product amounts to US\$ 218 billion UNCTAD [35]. The integration milestones achieved between East African Community (EAC) member states include customs union in force since 2005, the Common Market since 2010, the Monetary Union expected to be effective in 2023, and the still in progress Political Federation which is the ultimate goal of the community. The existence of EAC and implementation of its integration pillars virtually removes borders between member states, thus making diamonds within EAC more relevant as a source of competitiveness. The study will extend the diamond model to include other determinants so as to reflect on the consecutiveness of domestic diamond within the EAC. Furthermore, this study will include other factors which play a significant role in increasing the competitiveness of the dairy industry.

\subsection{The Extended Diamond Model}

Nations strive to increase the connectivity of their economies to others in an effort to boost their competitiveness. For instance, connectivity to other nations' diamonds can bring about an enhancing effect on the indigenous knowledge [36] [37], which in turn boosts its capability and productivity in resource allocation and increase in competitiveness. In fact, cross-border networks play a central role to increase a country's competitiveness. With the current degree of globalization, home base economic diamonds have become inextricably intertwined with other nations economic diamonds; therefore, it would be misleading to consider the home diamond as the only source of competitiveness for an economy [23]. For any industry in a country like Rwanda to develop and achieve competitiveness, a country which is landlocked, small in size, limited natural resources and underdeveloped human capital, its interaction and dealings with other nations plays a central role. In fact, an industry does not have to rely on a 
one country diamond, it can tap into other countries diamonds and selectively extract what it needs to fill the gap in the domestic diamond [33]. As FDI is well known for its attributes to convey to the host economy advanced knowledge and knowhow, capital and expertise in management [38] it would play a central role. In fact, the presence of foreign investor will have an enhancing impact on all determinants of the home diamond. According to Blomström, Kokko [39], FDI exerts an enhancing impact on the host country's human capital which plays a central role in the improvement of that country's competitiveness. Both the neoclassical and endogenous growth models can be used to highlight the central role of FDI in boosting the competitiveness of the national economy by interacting with determinants of the domestic diamond. According to the neoclassical growth theory, FDI can stimulate the economic growth by channeling capital to a productive sector so as to increase its marginal productivity. The neoclassical economy considers FDI as a more reliable and less volatile source of capital for the developing world which can drive the economic growth in a sustainable manner [40] [41] [42] [43]. Also, the endogenous growth theory attributes the long-run growth to efficient utilization of investment resources which is the result of technological progress, human skills, and managerial expertise brought about by FDI [44] [45] [46] [47]; thus, in the endogenous growth model, long-run economic growth is a function of technological progress which is generated through technology transfers and knowledge spillovers [48]. Furthermore, the presence of FDI in a country can influence the host government to improve and strengthen its institutions thus acting as an agent of change in the host country, this was confirmed in the study by Kwok and Tadesse [49] which indicated that foreign direct investment generates positive spillover effects on the institutional environment of host countries.

Basing on the above, it is clear that for FDI to lead to sustainable growth; it interacts with the determinants of the domestic diamond to enhance and upgrade their capability and productivity; of these determinants human capital plays an intermediary and central role. In fact, the effect of FDI on human capital would trigger a domino effect on the rest of the determinants and subsequently lead to overall competitiveness of the domestic national diamond. This is consistent with the study conducted by UNCTAD [50] which, after carrying out an investigation on FDI-led growth in developing countries indicated that FDI creates positive effect on employment, human skills and international trade for China and Taiwan. Also, trade plays a very important role especially in knowledge transfer and market access. In fact, the knowledge base of a country is influenced by both internal factors as well as external factors from other countries with which it has a certain amount of dealings due to their geographic proximity, regional integration or any other form of cross-border or trade agreements [51]. Trade can contribute to competitiveness of the domestic economy; in fact, export activities allow a country to integrate itself in the global supply chain and conduct business dealings with globally competitive firms and sophisticated market demand. As a result, this exerts pressure on the exporting 
firm to upgrade its operations and innovate so as to maintain its global position. On the other hand, import gives the domestic country access to intermediary and capital goods which are embedded with advanced knowledge and technology from other countries to improve the productivity of the domestic diamond factors [52], this allows technology laggard countries to borrow technology from the leading edge countries. However, developing countries are faced with shortage of source of finance and stock of capital which is crucial to any investment endeavor, and many of these countries are heavily indebted and solely have to rely on financial aid inflows [53]. Foreign aids have been used to address this issue with positive results reported in some cases. The study results by Durbarry, Gemmell [54] indicated that foreign aid stimulates growth in low income countries provided the existence of stable macroeconomic policy environment as well as trade liberalization in those countries. Foreign aid can contribute to the recipient country's economic performance by increasing investment in physical and human capital, increasing the capacity to import capital goods or technology thus promoting endogenous technical change [55].

Figure 1 depicts four factors which exert influence on the domestic diamond to stimulate its competitiveness. A, B and C represent diamonds of neighboring countries which have some level of connectivity with the domestic diamond through trade and cross-border people movement. The figure also displays other external factors which play a crucial role to boost the competitiveness of the domestic diamond such as FDI and ODA.

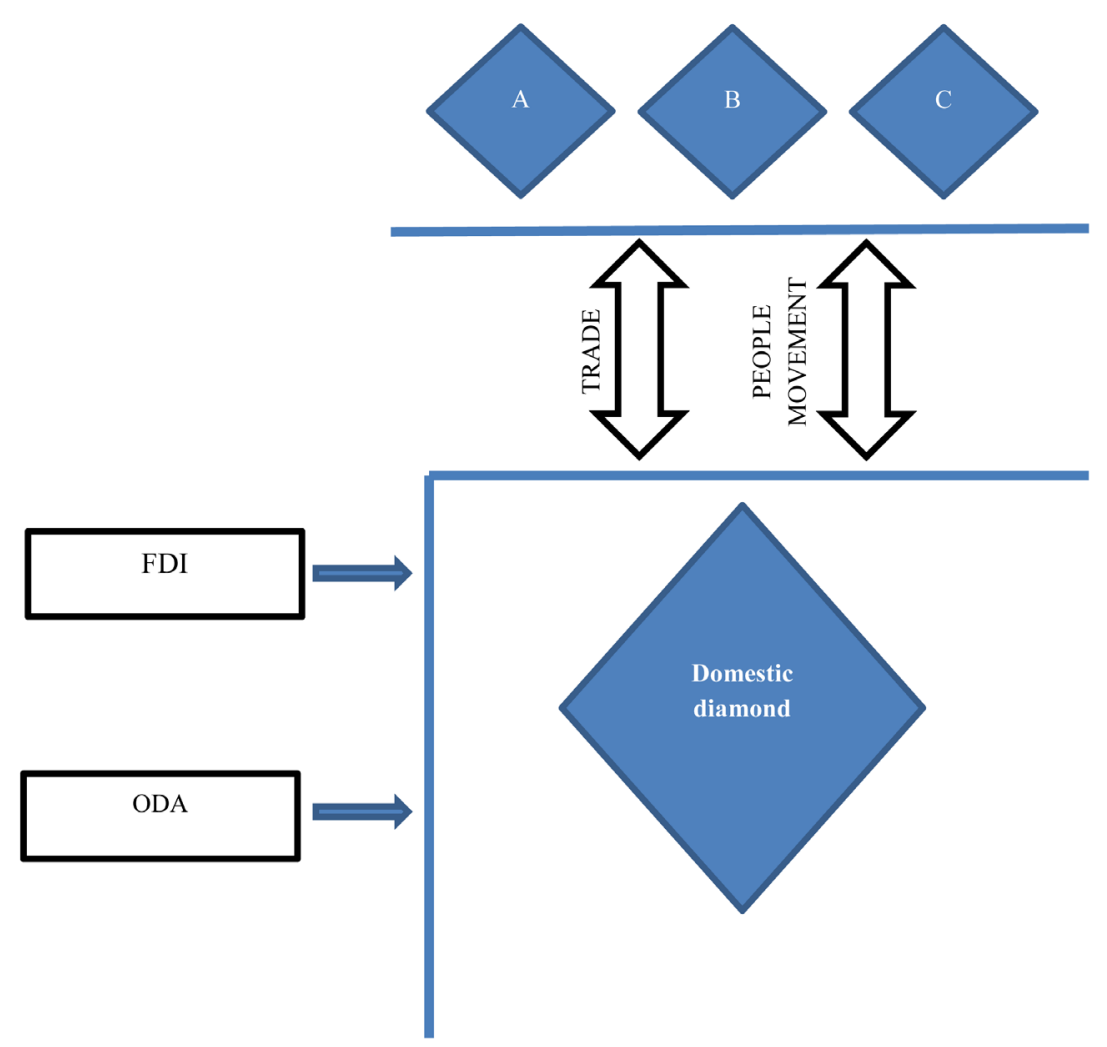

Figure 1. Conceptual model. 
Figure 1 depicts four factors which exert influence on the domestic diamond to stimulate its competitiveness. $\mathrm{A}, \mathrm{B}$ and $\mathrm{C}$ represent diamonds of neighboring countries which have some level of connectivity with the domestic diamond through trade and cross-border people movement. The figure also displays other external factors which play a crucial role to boost the competitiveness of the domestic diamond such as FDI and ODA.

\subsection{Analytical Framework: The Determinants of Rwanda Dairy Cluster Competitiveness}

Our analytical framework consists of extend porter's diamond to include other factors which are believed to significantly contribute to its competitiveness. Apart from determinants identified in the diamond model, 4 others have been added namely: the role of FDI, international trade, human mobility and the role of NGOs and development partners.

\section{Factors Conditions:}

The competitiveness is not determined by the stock of factors but the rate and efficiency with which they are created, upgraded and deployed in particular industries [15]. Therefore, in dairy industry, the number of cattle does not matter more than milk production efficiency. And to increase efficiency, the same or less amount of inputs should be able to give more output; for that to happen, ingenuity and innovativeness play a central role whereas inherited resources do not add much. In this regard, this study argues that the number of farmers and cattle head do not generate competitiveness in the Rwandan dairy industry cluster. This is exacerbated by prevailing land shortage in Rwanda. A number of strategies are being taken to tackle this issue; these include switching from local breed with low milk yield to exotic breed with high milk yield and zero grazing policy. However, more improvement should also be done to curb the production cost since exotic breeds require more than local breeds such as feeds and medicines. In 2016, the composition of cattle was reported to be $45 \%$ local breeds, $33 \%$ dairy cross-breeds, and $22 \%$ dairy pure breeds [4]. Zero grazing practice is also another achievement which reduced pressure on land demand. However, these achievements came with challenges which require further ingenuity. These include increased feed and nutritional value requirement for the new breeds coupled with weather fluctuation. This is still hindering the achievement of potential milk productivity of dairy cows. Only few farmers are using complementary feeding of concentrates to address this issue due to limited knowledge or high cost; in fact, the number of animal feed processing plants remains low and the quantity of imported raw materials used in these plants remains high. This makes the ratio of milk price to feed ratio too high, estimated at 1.2:1 milk price per liter to cost of concentrate per kilogram. This has inflicted adverse effect on milk profitability.

The geographic situation and location of Rwanda ${ }^{1}$ makes it vulnerable to

${ }^{1}$ Rwanda is a landlocked country and shares borders with four countries. 
Tick-Borne Diseases $\left(\mathrm{TBDs}^{2}\right)$. Import certificates and quarantines are the current tools used to address this issue.

Furthermore, animal health services delivery system in the country is well developed with well-equipped laboratories. The government provides veterinary services through district and sector well-equipped veterinary officers, who provide free drugs to dairy farmers. Moreover, these drugs can be imported duty and tax free. However, efficiency in this area is still undermined by high turnover of technicians, lack of regular refresher training, lack of access to advanced diagnostic technologies and their insufficiency in number [4].

We argue that programs initiated by the government which distribute cattle to poor families do not contribute to the competitiveness of dairy industry; on the contrary, it hinders productivity in this industry. Cattle farming should be left to dedicated professional famers; this would make it easy to identify existing bottlenecks along the value chain. The increase of unprofessional farmers scattered across the country does nothing more than increasing the informal trade which in turn contribute to the current inefficiency in the dairy industry [10] [56]. While we are of the opinion that this was a strategy to economically empower the local in line with their indigenous knowledge, we are of the view that other alternatives could have been used in a more efficient and effective way such as access to micro loans to start other business they deem profitable. Distribution of cows to household basing on the economic conditions is irrational, if given a change, most of the beneficiary would have opted for something else in which they have more and better experience and passion. In fact, reports have emerged that some people who were given cows were unable to raise them and ended up selling them [8]. Furthermore, most of beneficiary cannot achieve economies of scales given the small number of cows they are own. Thus, due to high production cost, most of them would simply rely on the weather for forage and suffer losses during dry seasons [8].

Regarding knowledge and skills of farmers, Farmers Field School (FFS) approach was used to train farmers and equip them with necessary skills to increase productivity and improve milk quality. However, farmers' knowledge as far as improved techniques and technology are concerned is still limited. Research capacity has also been affected by the transfer of Rwanda Agricultural Research Institute (ISAR) to a mixed animal research and extension programs within the Rwanda Agricultural Board (RAB) with previously highly specialized researchers being assigned to broad specialization areas in a large range of fields.

Regarding road access infrastructure, this area still has a long way to go, roads linking villages and farming to one another and to markets are in poor condition and inadequate. $70 \%$ of road network required to bring motorable road within 2 $\mathrm{km}$ of farms is in unacceptable condition with a roughness of more than $10 \%$. This leaves a significant proportion of rural population without access to transport facilities and market [57].

${ }^{2}$ These are mainly coast fever, foot and mouth disease, contagious bovine pleuropneumonia, and lumpy skin disease. 
Regarding financial services, facilities for access to a loan are only available to farmers who are members of cooperatives; this is a major constraint since most of farmers are not members of any cooperatives, only about $2 \%-7 \%$. Moreover, most of smallholder dairy farmers are limited by low level of financial literacy therefore do not use banking services.

\section{Demand conditions:}

As Porter [15] puts it, it is not about the size of the market but the intensity and sophistication of the demand that is significant for competitive advantage; sophisticated consumer put pressure on firms to produce sophisticated products which will result into a progressive competitive advantage of the country in that production. Here, we explore sophistication of the domestic demand of dairy products which can be exploited by the industry to develop its competitive advantage.

The projected milk supply and demand carried out by RDDP in 2016 shows a widening gap between the supply of milk and growing demand. However, this gap cannot be removed by increasing the number of cattle given the prevailing shortage of land in Rwanda; on the contrary, innovative measures such as mixed race cows and improved cattle feed would make a huge contribution and lead to increased productivity and competitiveness of the industry by increasing milk yield per cow.

Another important characteristic of the domestic demand for dairy products in Rwanda relates to the link between the culture and dairy products. As aforementioned, dairy processing is deeply rooted in Rwandan culture, local consumers demand both tasty, high quality dairy products and diversity. But at the same time, the demand is quite elastic. These factors put enormous pressure on the dairy industry and act as impetus to innovation so as to increase efficiency and improve productivity along the value chain.

\section{Related and supporting industries:}

Proximity with home-based suppliers and related industries that are internationally competitive facilitates the free flow of information and technical interchange which drive the pace of innovation and upgrading; also, the presence of related industries in the same geographic location increases the likelihood of new skills and may give rise to new competitive business approach [15]. A business environment with related suppliers, competitors and complementary firms constitutes a breeding ground for the development of competitive advantage of the cluster [58]. Also, the presence of internationally competitive suppliers would give firms in the cluster access to cost-effective inputs in an efficient, early, rapid, and at times preferential way [15].

However, this is still a challenge in Rwanda, particularly in the dairy industry. Most of the required supplies such as milk coolers, insulated tanks for transportation as well as basic testing kits and processing equipment are not readily available in the country. All equipment and most of inputs products are imported; this has resulted in high production cost of dairy products. 


\section{Firm strategy, structure and rivalry}

New practices initiated by the government among cattle farmers such as intensive growth strategy by giving them exotic breeds and reducing the number of local breeds pose as a source of competitive advantage. Coupled with zero-grazing system, this is putting pressure on farmers to improve animal feeding and feed conservation by increasing efficiency and ceasing to rely on natural resources and weather in particular. Farmers are keen to acquire knowledge and skills to address this challenge by innovating. Given that the dairy industries in the neighboring countries are not faced with the same challenges and constraints, the dairy industry in Rwanda is well positioned to benefit in the long-run; these challenges and constraints are acting as signals calling farmers in Rwanda to innovate. Furthermore, artificial insemination has greatly contributed to a reduction of local breed among cattle heard in Rwanda. However, this has also come with further challenges. Due to inability of exotic breeds to adapt to local weather and their vulnerability to animal diseases in the region, research institutions in the country such as ISAR have been pushed to carry out further research in the area of artificial insemination. Working in cooperatives would also give farmers the ability to pool funds and make more investment in improving their efficiency and productivity. Therefore, working in cooperative as a strategy would give rise to competitive advantage in the industry. For instance, Milk Collection Centers (MCCs) which are owned by farmers 'cooperatives have made a significant contribution to ensuring good quality of milk and efficiency during milk collection process. However, as aforementioned, membership of dairy farmers in cooperatives is still low, about $4 \%$ of dairy farmers are members of any cooperatives [4].

The market structure of dairy products is a monopolistic competition; this is acting as a stimulus to make improvement on efficiency and productivity as well as marketing strategy of dairy products. Subsequently, for processed milk to appeal to more consumers instead of boiled milk sold by informal traders, dairy processors are using retail points operated as a franchise; those put in place by Inyange are known as "milk zone" and those put in place by Crystal dairies are known as "milk point". The franchise arrangement is between dairy processors and traders who are required to ensure good management and hygienic practices while marketing the dairy products. This model is proving to be successful by reducing production cost since it does not require packaging materials.

\section{The role of the government:}

The primary role of the government is to create an enabling environment by putting in place policies, laws, strategies and institutions to facilitate their enforcement and implementation.

The policy framework governing operations of the dairy sector was formulated in 2004 as part MINAGRI's Animal Resources Policy (2004). In its section regarding dairy issues, the policy puts emphasis on raising milk production to address low per capita milk availability. Moreover, subsequent to land reform 
policy (2004) and Act (2005), the dairy farming approach was changed from extensive communal grazing systems to more intensive smallholder systems with emphasis on increasing production through changes to grazing systems, improved breeds and genetic profile of dairy cows, incentives for creation of farmer associations, integrated livestock/farming systems, improved animal feed and performance, decentralization of service delivery, increased linkages between training, research and extension; as well as overall creation of an enabling environment for the dairy industry.

Also, several other policies, laws, strategies and plans have been put in place to stimulate the increase of production and consumption of milk and other dairy products. These include: Animal Health Law (2008); Animal Nutrition Strategy (2009); the Milk Value Chain Master Plan (2009); National Dairy Strategy (2013-2018); Charter for "One Cup of Milk per Child" programme (2014); Strategic Plan for Mastitis Prevention and Control in Rwanda (2015); Rwanda Breeding Policy and National Herd Book (2015); and Ministerial order on milk hygiene (2015); and one Cow per poor family program.

A number of institutions have been put in place also to enforce and implement the above mentioned policies, laws, strategies and plans such as Ministry of Agriculture and Animal Resources (MINAGRI) which have the primary responsibility for the animal production and farming aspects of the dairy industry; Rwandan Agricultural Board (RAB); Rwanda Agriculture and Livestock Inspection Certification Services (RALIS); National Agricultural Export Board (NAEB); Rwanda Standards Board (RSB) and Rwanda Environmental Management Authority (REMA).

Other institutions which play key roles in the dairy industry of Rwanda are:

- Rwanda National Dairy Platform: This is a multi-stakeholder private organization for advocating and campaigning for interests of business operators in the dairy industry. It also brings together the government and development partners.

- Rwanda Veterinary Doctors Council: it is a statutory body of veterinary doctors and other professionals in the livestock sectors. Its main mandate is to certify and regulate the work of veterinary doctors.

- National Dairy Farmers' Federation of Rwanda (NDFFR).

- Rwanda Milk Sellers' Association (RMSA).

- Rwanda Dairy Processors Association (RDPA).

- Rwanda Cheese Makers Company (RCMC).

- Dairy Quality Assurance Laboratory (DQAL).

\section{The role of FDI:}

FDI come with capital and advanced knowledge and technology [38]. Despite that their involvement in the Rwandan dairy industry cluster is still minimal, but their contribution to competitiveness cannot be ignored. Brookside Dairy, the largest multinational dairy processor in the region based in Kenya, has attracted investments from Aureos Capital, a private equity fund that raised money from 
North American and European investors; Dubai-based private equity firm Abraaj Group, and Danone, a French multinational company [56]. The new capital from these multinationals was used in the acquisition of Kenya local dairies (Delamere, Spinknit and Buzeki Dairies) and for expansion of its operations in Uganda and Tanzania and plans to expand to South Sudan [59]. In Uganda, Brookside acquired Sameer Agriculture \& Livestock Ltd. (SALL) in 2015; discussions are ongoing on the acquisition of Inyange Industries in Rwanda and shares in Elemtu Dairy in Ethiopia. The Nestle is another multinational which is involved in EAC dairy industry; currently it is carrying out pilot studies on quality improvement schemes in Western Kenya with plans to expand its operations to Uganda, Rwanda and Tanzania.

In Uganda, the establishment of Pearl Dairies in 2013 attracted USD 8 million by International Finance Corporation in 2014; and a USD 25 million for the establishment of Amos Dairies in 2014. Other international business associations such as the Netherlands African Business Council's Dutch Dairy Partners group are actively involved in the region. Related and supporting industries is also emerging with equipment and inputs suppliers, such as animal breeding material and services, farm equipment, processing equipment and ingredients for dairy products present in the region with plans to set up manufacturing, distribution or services operations.

International trade:

International trade has been linked to transfer of knowledge and technology [60] [61] [62], importing machinery and equipment has been found to be an important channel to acquire foreign knowledge and technology and enhance competitiveness. The study conducted by Xu and Wang [63] found that trade of capital goods contribute more to knowledge and technology transfer due to their technological content and knowledge embodied in their structure. Therefore, when a country imports a machine with advanced technology embedded in it, it becomes able to produce high quality products. If that country wishes to start domestic production of that machine, it may have to copy the imported one by reverse engineering which becomes easier since by hands-on experiment and learning. For the case of the Rwandan dairy industry cluster, imported capital goods such as dairy equipment and production machines improve the quality of dairy products as well as their competitiveness. In some instances, through reverse engineering, previously imported machines could start to be locally produced following high import tariff.

\section{Human mobility}

Human mobility across borders can influence knowledge and technology transfer [64]. In fact, spending some times in a more technologically advanced country provide migrants with unique opportunity to have exposure and hands-on experience of advanced technology and knowledge with they can apply once back to their home countries. In the case of Rwandan dairy industry cluster, three of its neighboring countries namely Kenya, Tanzania and Uganda pos- 
sess relatively advanced dairy industry in terms of production, efficiency and technology [59] [65]. The experience acquired by people returning to Rwanda from those countries can be exploited to improve and upgrade production process in the dairy industry. This can help to remove some bottlenecks along the value chain and stimulate competitiveness of the industry.

\section{The role of NGOs and development partners:}

As a least developed country, Rwanda economic development is highly supported by foreign assistance. Assistance can consist of financial support, technical support, research and development, capacity building, animal health supplies and equipment, supply of improved milk cows to rural households as well as infrastructure development and upgrading. NGOs and development partners contribution influences efficiency, management and marketing strategies in dairy industry. These organizations serve as the main source of external knowledge and innovation for the dairy industry cluster. In addition, due to their expertise in the field, coupled with their reputation with both the government and the people, they serve as a bridge between the government and individual in the dairy industry cluster by advising policy issues related to dairy industry development as well as ensuring their implementation by all stakeholders. In a way, the presence of NGOs and development partners in the Rwandan dairy industry fills the gap of small involvement of FDI in this industry. In fact, these organizations serve as channels of advanced knowledge and technology from advanced economies which would otherwise be brought about by FDI. The minimal involvement of FDI in this industry is due to its perceived low attractiveness to MNEs.

\subsection{Rwanda Dairy Value Chain}

First, farmers acquire agro-inputs and artificial insemination; thereafter, milk is produced and transported to be sold to MCCs. MCCs chills collected milk, and supplies to the processing plant which produce pasteurized milk, UHT milk, flavored milk, ghee, both salted and unsalted butter and yoghurt. The processing plants distribute milk and other derived products to the milk zones which carry out the distribution to retailers.

\section{Milk production:}

As aforementioned, livestock, especially dairy cattle, is deeply rooted in the culture and history of Rwanda and thus it has always been an indispensable part of the production systems in the economy of the country. Remarkable progress has been made since the 1994 tragedy to rebuild the cattle livestock, especially through the program of "one cow for poor family" initiated by the government [6]. Now the cattle population has increased from the pre-1994 level of 600,000 heads to $1,349,792$, which include 615,631 (45\%) local breeds, 439,414 (33\%) dairy cross-breeds, and 294,747 (22\%) dairy pure breeds [4].

Governments programs such as One Cow per Poor Family, improved access to artificial insemination, animal health and animal husbandry services to fa- 
mers as well as cooperatives were the main contributors to improved productivity and increased production in the dairy sub-sector. Subsequently, the milk yield registered a record increase, from 628,266 tons in 2013 to 706,030 tons in 2014 [66]. Furthermore, the number of cattle famers has been on the hike, according to NISR [67] Percentage of livestock-owning households rearing cattle has increased from $34.4 \%$ in 2006 to $50.4 \%$ in 2014 . Due to scarcity of land, the government has encouraged farmers to practice intensive growth strategy by giving them exotic breeds which gives a higher milk yield than local breeds; moreover, farmers were discouraged to practice open-range system which was common among farmers [7]. However, zero-grazing system requires higher production cost compared to other systems, thus there is a need for high value dairy market to support those costs [68]. Operating through cooperative would give farmers the advantage of economies of scales in their operations; however, most of them still operate individually.

\section{Milk collection \& Trade.}

This is mostly done by individual transporters and traders who use low quality standards in this process; as a result, the quality of milk is affected and thus the quality of the derived products [56]. Some of the transporters bypass the processing plant due to low pay and take the milk straight to the market. In this case, the milk would be processed by the end consumer using artisanal method. The amount of milk which is sold in this way accounts for about $85-90 \%$ of milk marketed [59]. This uncoordinated process in collection of milk from dairy farms had diverse impact on the quality and often led to low capacity utilization of dairy processing plants. To address this issue, in December 2015 the government has issued a Ministerial Order regulating the collection, transportation and selling of milk. According to this Ministerial Order, all milk sold in the country is first collected at a place where its quality is tested. This Ministerial Order divides milk collection sites into two categories: A simple sheltered milk collection sites and modern milk collection centers.

\section{A simple sheltered milk collection sites:}

This simply consists of a structure that provides shade, is close to a road, sheltered from dust, and is equipped with clean containers (aluminum milk cans) and milk testing equipment (at least an alcohol-gun; lactodensimeter and thermometer). Given the current milk production in the country, about 2000 milk collection sites would be needed to fill the gap [4].

\section{Milk collection centers:}

This should meet a number of specifications in terms of construction, and utilities (availability of water and electricity) as well as milk testing facilities. Currently, 100 MCCs meet these specifications.

For efficiency purpose, the ownership and management of MCCs was supposed to be taken over by cooperatives as business units that were supposed to provide services in milk bulking and marketing as well as farmer training, credit, and veterinary services and inputs to cooperative members [10]. However, only 
a few number of cooperatives are operational and most of farmers are not part of any of them [4]. It follows that some of MCCs are experiencing the problem of electricity shortage, poor maintenance, and access to clean water, poor management and inefficiency along the supply chain; all these factors have resulted in underutilization of their capacities whereby only $25 \%-30 \%$ of the total installed capacity is being utilized [68]. Given the current levels of milk sold across the country, about 177 MCCs with the capacity utilization of about $85 \%-100 \%$ would be needed to fill the gap.

Furthermore, poor conditions of the roads from production farms to MCCs affect the quality of milk and decrease efficient milk supply. According to estimates by the Rwanda Transport Development Agency (RTDA), about 85\% of feeder roads (District Class II roads) are in poor conditions.

Value addition and processing:

Estimates show that the current processing capacity of Rwanda is $280 \mathrm{MT}$ per day, but only about $35 \%-40 \%$ is utilized [4]. There are seven leading milk processing plants and approximately 25 - 30 small and medium scale processors of cheese and other dairy products. These include Inyange Industries, Crystal Industries Nyanza Dairy, Savanah Dairy, Haji Dairy, Blessed Dairies, Mukamira Processing Plant, and Burera Dairies. Inyange Industries is the current market leader with $75 \%$ of market share; its production capacity is about $80 \mathrm{MT}$ per day [4].

Processing plants are faced with several issues such as insufficient and unstable milk supply, low milk quality, existence of informal milk market leading to low capacity utilization which result into high production cost due to failure to achieve economies of scales [10] [56]. As a result, milk and other dairy products processed in Rwanda are highly priced in comparison to dairy products from neighboring countries.

The variety of products produced by dairy processors are still limited; the main products are pasteurized whole and skimmed milk, fermented milk, UHT milk, fresh cream, flavored milk, ghee, salted and unsalted butter, mozzarella cheese and yoghurt [59] [68].

Distribution and retail:

Once processed, dairy products are taken to consumers through several distribution channels, such as supermarkets, hotels, restaurants, and Rwandair [59]. Inyange and Crystal Industries have introduced a new innovative distribution strategy by establishing outlets known as "Milk Zones" which sell high quality pasteurized milk which is unpacked to keep the price low, customers bring in their own containers; this strategy has made the price of unpackaged pasteurized milk competitive vis-à-vis informal traders. So far, about 81 milk zones have been established by Inyange Industries while 30 have been established by Crystal Industries [68]. This has boosted the demand level of pasteurized milk [56] [59] with a reported increase of 78,000 liters of milk processed per day by 2016 [68]. Also, the dairy processors the Milk Zones as one-stop point for their other dairy products. 
The stage of retail is dominated by informal traders who approximately sell $75 \%-80 \%$ of the milk sold in the country [68]. Some traders collect milk from farmers and sell it to other intermediaries such as MCCs; some others prefer to collect milk from farmers and sell it as hawkers to the end consumers or through their own kiosks. However, this practice is characterized by unhygienic practices which do not meet food safety standards such as adulteration and untested milk. To address this issue, the government has issued a Ministerial Order on milk collection, transportation and marketing in 2015 which has laid out requirements and standards regarding food safety in the dairy sector. Figure 2 shows the map of the Rwandan value chain.
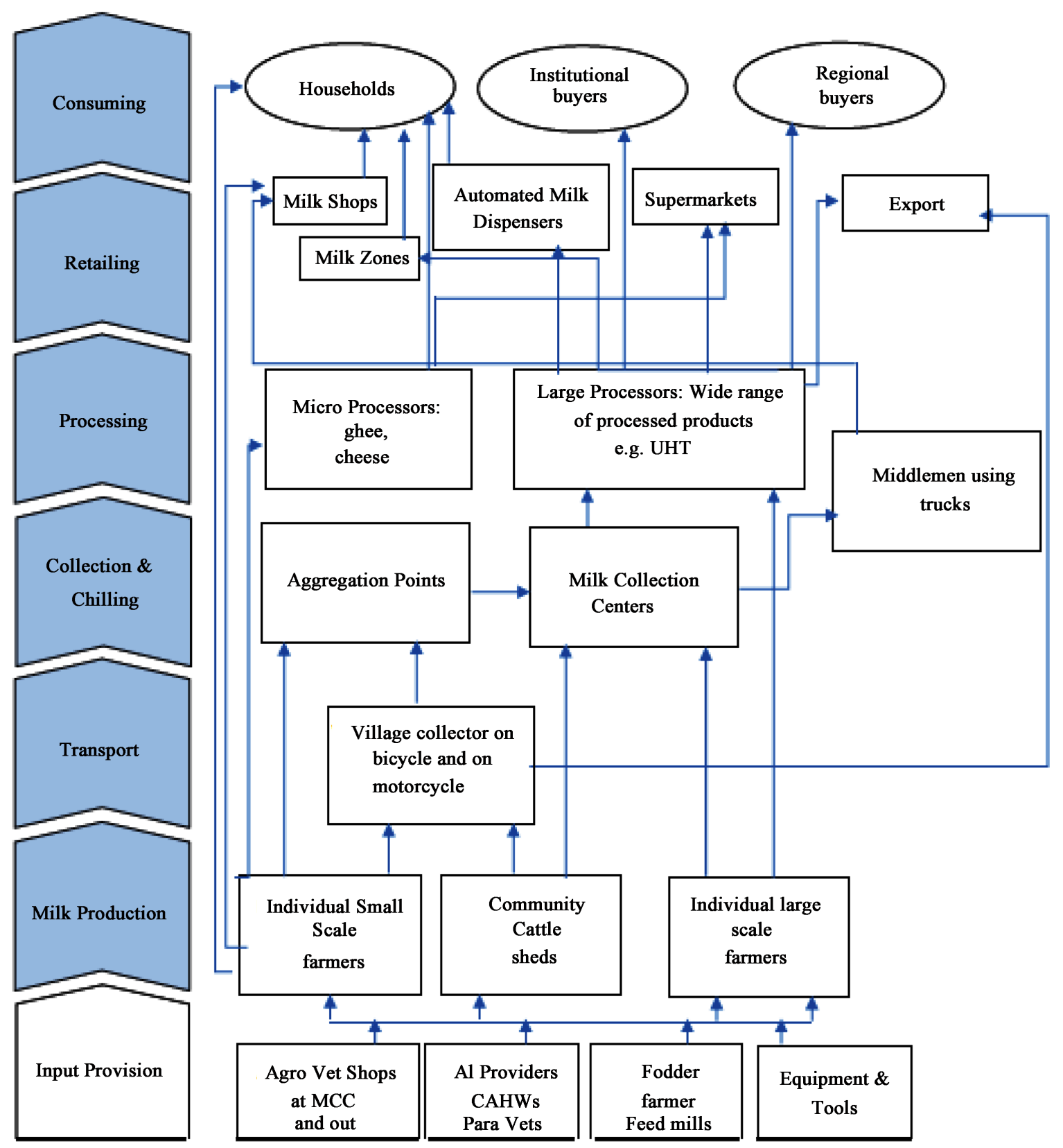

Figure 2. Dairy value chain map. Source: Heifer project international (2016). 


\section{Methodology and Data Description}

\subsection{Methodology}

To test how competitiveness of the influence of our extended diamond on the Rwandan dairy industry cluster, time series data will be used. Time series data are known for their dynamic relationship, which implies that a change in one variable now has an impact on that same variable, or other variables, in one or more future time periods [69]; thus, a contemporaneous and lagged relationship between independent and dependant variables. Moreover, Augmented Dickey Fuller test statistic reveal that our data are I(0) and I(1). For that effect, the autoregressive distributed lag (ARDL) model will be considered. An ARDL model can be written as follows:

$$
y_{t}=\alpha+\sum_{i=1}^{p} \gamma_{i} y_{t-i}+\sum_{j=1}^{k} \sum_{i=0}^{q_{j}} x_{j, t-i} \beta_{j, i}+\varepsilon_{t}
$$

where: $p$ denotes the number of lags of the dependent variable, $q_{1}$ is the number of lags of the first explanatory variable, and $q_{k}$ is the number of lags of the $k$-th explanatory variable. In that model, some of the regressors may be dynamic (with at least one lagged term) or static $\left(q_{l}=0\right)$.

$\varepsilon_{t}$ represents the innovations.

To run the test, we allow for linear trend and include the intercept as fixed regressors, the maximum number of lags for both the dependent variable and the principal regressor is set to be 4; Alkaike info criterion (AIC) was selected as the basis for determining the lag orders for the regressors (see Table 1). To ensure that the errors of this model are serially independent, the residual diagnostics test (CORRELOGRAM-Q-STATISTICS) will is run (see Table 2).

Arch test will also be run to test heteroscedasticity (see Table 3); to test the long-run relationship, a bound test will be performed (see Table 4).

\subsection{Model Specification}

Competitiveness: The competitiveness of the dairy industry cluster will be proxied by Lafay Index which measures the competitiveness of the total foreign trade in a specific product by using both import and export flows [70]. Lafay index can be used to gauge specialization of an industry as a source of competitiveness. Lafay index can be defined as:

$$
L F I_{i j}=100 *\left(\frac{X_{i j}-M_{i j}}{X_{i j}+M_{i j}}-\frac{\sum_{i=1}^{n}\left(X_{i j}-M_{i j}\right)}{\sum_{i=1}^{n}\left(X_{i j}+M_{i j}\right)}\right) * \frac{X_{i j}+M_{i j}}{\sum_{i=1}^{n}\left(X_{i j}+M_{i j}\right)}
$$

where:

$L F I_{i j}$ : denotes the Lafay Index in a specific country's trade in the ith of products with the th market.

$X_{i j}$ : A specific country's export of the $i$ th products, in this case dairy products, to the $j$ th market.

$M_{i j}$ : A specific country's import of the ith products, in this case, the dairy products, to the outside market. 
Table 1. ARDL.

\begin{tabular}{|c|c|c|c|c|}
\hline \multicolumn{5}{|c|}{ Dependent Variable: LAFAY_INDEX } \\
\hline \multicolumn{5}{|c|}{ Method: ARDL } \\
\hline \multicolumn{5}{|c|}{ Date: 01/19/18 Time: 20:40 } \\
\hline \multicolumn{5}{|c|}{ Sample (adjusted): 19742015} \\
\hline \multicolumn{5}{|c|}{ Included observations: 42 after adjustments } \\
\hline \multicolumn{5}{|c|}{ Maximum dependent lags: 4 (Automatic selection) } \\
\hline \multicolumn{5}{|c|}{ Model selection method: Akaike info criterion (AIC) } \\
\hline \multicolumn{5}{|c|}{ Dynamic regressors (4 lags, automatic): LOG_DVPT_ASS } \\
\hline \multicolumn{5}{|c|}{ LOG_FDI_INFLOW LOG_GDP_CAP LOG_MILK_CATTLE } \\
\hline \multicolumn{5}{|c|}{ TRADE_OPEN } \\
\hline \multicolumn{5}{|c|}{ Fixed regressors: @DURING (“1994”) C @TREND } \\
\hline \multicolumn{5}{|c|}{ Number of models evalulated: 12500} \\
\hline \multicolumn{5}{|c|}{ Selected Model: $\operatorname{ARDL}(2,4,4,4,3,3)$} \\
\hline Variable & Coefficient & Std. Error & t-Statistic & Prob.* $^{*}$ \\
\hline LAFAY_INDEX $(-1)$ & -0.823563 & 0.247150 & -3.332241 & 0.0049 \\
\hline LAFAY_INDEX $(-2)$ & -1.405002 & 0.346213 & -4.058204 & 0.0012 \\
\hline LOG_DVPT_ASS & 2.501586 & 2.203217 & 1.135424 & 0.2753 \\
\hline LOG_DVPT_ASS $(-1)$ & 1.620644 & 2.171204 & 0.746426 & 0.4678 \\
\hline LOG_DVPT_ASS $(-2)$ & 0.999750 & 2.142857 & 0.466550 & 0.6480 \\
\hline LOG_DVPT_ASS $(-3)$ & -6.852759 & 1.707993 & -4.012169 & 0.0013 \\
\hline LOG_DVPT_ASS $(-4)$ & -5.377336 & 1.855227 & -2.898479 & 0.0117 \\
\hline LOG_FDI_INFLOW & -0.774124 & 0.498158 & -1.553973 & 0.1425 \\
\hline LOG_FDI_INFLOW $(-1)$ & 0.517173 & 0.394201 & 1.311954 & 0.2106 \\
\hline LOG_FDI_INFLOW $(-2)$ & 0.214468 & 0.374172 & 0.573180 & 0.5756 \\
\hline LOG_FDI_INFLOW $(-3)$ & -0.676900 & 0.442465 & -1.529837 & 0.1483 \\
\hline LOG_FDI_INFLOW (-4) & -0.511473 & 0.223753 & -2.285886 & 0.0384 \\
\hline LOG_GDP_CAP & 5.093924 & 6.059788 & 0.840611 & 0.4147 \\
\hline LOG_GDP_CAP $(-1)$ & 0.174442 & 5.583309 & 0.031244 & 0.9755 \\
\hline LOG_GDP_CAP $(-2)$ & 11.46354 & 6.726872 & 1.704142 & 0.1104 \\
\hline LOG_GDP_CAP $(-3)$ & 3.291511 & 6.644939 & 0.495341 & 0.6280 \\
\hline LOG_GDP_CAP $(-4)$ & -11.55660 & 5.354352 & -2.158356 & 0.0488 \\
\hline LOG_MILK_CATTLE & -13.22901 & 3.225018 & -4.101994 & 0.0011 \\
\hline LOG_MILK_CATTLE $(-1)$ & -9.635914 & 3.545966 & -2.717430 & 0.0167 \\
\hline LOG_MILK_CATTLE $(-2)$ & -10.34610 & 3.510971 & -2.946791 & 0.0106 \\
\hline LOG_MILK_CATTLE $(-3)$ & 3.434072 & 2.812778 & 1.220883 & 0.2423 \\
\hline TRADE_OPEN & -0.063797 & 0.067714 & -0.942159 & 0.3621 \\
\hline TRADE_OPEN $(-1)$ & 0.037348 & 0.050024 & 0.746607 & 0.4677 \\
\hline TRADE_OPEN $(-2)$ & 0.189687 & 0.060370 & 3.142065 & 0.0072 \\
\hline TRADE_OPEN $(-3)$ & 0.072023 & 0.069839 & 1.031263 & 0.3199 \\
\hline @DURING (“1994”) & 0.985069 & 7.456168 & 0.132115 & 0.8968 \\
\hline
\end{tabular}




\section{Continued}

\begin{tabular}{ccccc}
\hline C & 408.7503 & 108.2923 & 3.774508 & 0.0021 \\
@TREND & 1.381514 & 0.316357 & 4.366943 & 0.0006 \\
R-squared & 0.902071 & Mean dependent var & -1.463571 \\
Adjusted R-squared & 0.713208 & S.D. dependent var & 1.741199 \\
S.E. of regression & 0.932463 & Akaike info criterion & 2.932748 \\
Sum squared resid & 12.17283 & Schwarz criterion & 4.091194 \\
Log likelihood & -33.58770 & Hannan-Quinn criter. & 3.357364 \\
F-statistic & 4.776328 & Durbin-Watson stat & 2.447179 \\
Prob (F-statistic) & 0.001786 & & \\
\hline
\end{tabular}

*Note: p-values and any subsequent tests do not account for model selection.

Table 2. Correlogram-Q-statistics.

\begin{tabular}{|c|c|c|c|c|c|c|}
\hline \multicolumn{7}{|c|}{ Date: 01/19/18 Time: 20:02 } \\
\hline \multicolumn{7}{|c|}{ Sample: 19702016} \\
\hline \multicolumn{7}{|c|}{ Included observations: 42} \\
\hline \multicolumn{7}{|c|}{ Q-statistic probabilities adjusted for 2 dynamic regressors } \\
\hline Autocorrelation & Partial correlation & & $\mathrm{AC}$ & PAC & Q-Stat & Prob $^{*}$ \\
\hline$* *||$. & $* *||$. & 1 & -0.233 & -0.233 & 2.4377 & 0.118 \\
\hline.$*|\cdot|$ & $* *|\cdot|$ & 2 & -0.204 & -0.273 & 4.3630 & 0.113 \\
\hline.$|\cdot|$ &.$*|\cdot|$ & 3 & -0.036 & -0.183 & 4.4254 & 0.219 \\
\hline$. * \mid$ & $* *||$. & 4 & -0.131 & -0.299 & 5.2603 & 0.262 \\
\hline$.\left.\right|^{*} . \mid$ &.$|\cdot|$ & 5 & 0.196 & -0.000 & 7.1758 & 0.208 \\
\hline.$*||$. &.$*||$. & 6 & -0.106 & -0.201 & 7.7539 & 0.257 \\
\hline.$*||$. & $* *||$. & 7 & -0.083 & -0.206 & 8.1161 & 0.322 \\
\hline$.\left.\right|^{*} . \mid$ &.$*||$. & 8 & 0.091 & -0.124 & 8.5711 & 0.380 \\
\hline.$*||$. &.$* 1$ & 9 & -0.067 & -0.202 & 8.8244 & 0.454 \\
\hline$.\left.\right|^{*} . \mid$ &.$||$. & 10 & 0.172 & -0.009 & 10.527 & 0.396 \\
\hline.$*||$. &.$* 1$ & 11 & -0.130 & -0.202 & 11.533 & 0.400 \\
\hline.$*||$. & ${ }^{* *}||$. & 12 & -0.095 & -0.231 & 12.089 & 0.439 \\
\hline$.\left.\right|^{*} . \mid$ &.$*||$. & 13 & 0.174 & -0.100 & 14.013 & 0.373 \\
\hline.$||$. &.$||$. & 14 & 0.032 & -0.019 & 14.082 & 0.444 \\
\hline.$*||$. & ${ }^{* *}||$. & 15 & -0.141 & -0.291 & 15.435 & 0.421 \\
\hline.$||$. &.$*||$. & 16 & 0.017 & -0.181 & 15.455 & 0.492 \\
\hline.$||$. &.$*||$. & 17 & 0.024 & -0.169 & 15.497 & 0.560 \\
\hline$.\left.\right|^{*} . \mid$ &.$||$. & 18 & 0.165 & -0.017 & 17.592 & 0.483 \\
\hline.$*||$. &.${ }^{*} .1$ & 19 & -0.076 & -0.105 & 18.054 & 0.519 \\
\hline$. * \mid$ &.$* 1$ & 20 & -0.091 & -0.066 & 18.745 & 0.538 \\
\hline
\end{tabular}

*Probabilities may not be valid for this equation specification. 
Table 3. Arch test.

\begin{tabular}{clcl}
\hline & \multicolumn{4}{l}{ Heteroskedasticity Test: ARCH } & \\
\hline F-statistic & 0.033252 & Prob. F $(1,39)$ & 0.8563 \\
Obs ${ }^{*}$ R-squared & 0.034928 & Prob. Chi-Square (1) & 0.8517 \\
\hline
\end{tabular}

Table 4. Bound test.

\begin{tabular}{ccc}
\hline \multicolumn{3}{c}{ ARDL Bounds Test } \\
\hline \multicolumn{3}{c}{ Date: $01 / 19 / 18$ Time: $20: 08$} \\
Sample: 19742015 \\
Included observations: 42 \\
Null hypothesis: No long-run relationships exist \\
Test statistic & Value & $\mathrm{k}$ \\
F-statistic & 11.47478 & 5 \\
& Critical value bounds & \\
Significance & $\mathrm{I}(0)$ bound & 3.79 \\
$10 \%$ & 2.75 & 4.25 \\
$5 \%$ & 3.12 & 4.67 \\
$2.5 \%$ & 3.49 & 5.23 \\
$1 \%$ & 3.93 &
\end{tabular}

$n$ : agri-food products.

Lafay Index will be computed using data retrieved from FAO online database. Using LFI as our proxy for competitiveness, Equation (1) becomes:

$$
L F I_{t}=\alpha+\sum_{i=1}^{p} \gamma_{i} L F I_{t-i}+\sum_{j=1}^{k} \sum_{i=0}^{q_{j}} x_{j, t-i} \beta_{j, i}+\varepsilon_{t}
$$

\subsection{Data source and Description of Variables}

Our data sample consists of annual time series (1970 throughout 2016). Our main sources of data are the online database of the World Bank and Food and Agriculture Organization of the United Nations (FAO). However, the variable of human movement has been omitted due to availability of data.

\section{Dependent variable:}

Competitiveness: As mentioned above, the competitiveness of the dairy industry cluster will be proxied by Lafay Index which measures the competitiveness of the total foreign trade in a specific product by using both import and export flows [70].

Lafay Index will be computed using data retrieved from FAO online database. Independent variables:

- Development assistance: as above mentioned, the development assistance granted to Rwanda has an influence on the competitiveness of its dairy clus- 
ter industry. Data of development assistance will be retrieved from the world development indicators of the World Bank database.

- FDI inflows: Due to their advanced knowledge and technology, FDI inflows are expected to have a positive influence on the competitiveness of the dairy cluster industry. FDI inflows data will be retrieved from the world development indicators of the World Bank database.

- Market condition: the sophistication level of the domestic market can be the source of pressure to the industry to innovate thus boosting their competitiveness to satisfy the market demand; therefore, the market sophistication will be proxied by GDP per capita. In fact, as the income of the population in the domestic market increases, their awareness about dairy products increases and their quality requirements increases as well.

- Factor conditions: Due to efforts by the government to increase the number of milk cows in order to boost competitiveness of the industry, this study will consider milk cows as a proxy of factor conditions.

- Trade: As above mentioned, trade can influence competitiveness of the dairy industry. In fact, import of capital goods such as machines and other agriculture equipment can contribute to efficiency and greater productivity in the industry. Therefore, trade openness (export plus import as a share of GDP) will be our proxy in this regard.

- Dummy variable: the tragic event of 1994 will be proxied by a dummy variable to reflect its effect on the competitiveness of the dairy cluster industry.

\subsection{Test Results and Discussion}

As shown in Table 1, we have allowed for linear trend and included the intercept as fixed regressors, the maximum number of lags for both the dependent variable and the principal regressor is set to be 4; Alkaike info criterion (AIC) was selected as the basis for determining the lag orders for the regressors.

\section{Autocorrelation test}

It is important that the errors of this model are serially independent to ensure the consistence of parameters estimates. To that end, residual diagnostics (CORRELOGRAM-Q-STATISTICS) is performed with the following results shown in Table 2.

As shown in Table 2, the p-values strongly suggest that there is no evidence of autocorrelation in the model's residuals.

\section{Test of heteroscedasticity:}

As shown in Table 3, the Arch test of heteroscedasticity reveals that the residuals are homoscedastic.

\section{Bound test:}

To test the long-run relationship between the variables a bound test is performed with the following results:

As shown in Table 4, F-statistic of 11.47478 clearly exceeds even the $1 \%$ critical value for the upper bound, the null hypothesis of no long-run relationship is therefore rejected. 
As shown in Table 5, the error correction coefficient is negative and very significant as required.

The above findings in Table 6 reveal that the development assistance has a significantly negative impact on the competitiveness of the dairy cluster industry; this may be due to insufficient development assistance allocated to dairy cluster industry.

Table 5. ARDL cointegrating and long run form.

\begin{tabular}{|c|c|c|c|c|}
\hline \multicolumn{5}{|c|}{ Dependent variable: LAFAY_INDEX } \\
\hline \multicolumn{5}{|c|}{ Selected model: ARDL $(2,4,4,4,3,3)$} \\
\hline \multicolumn{5}{|c|}{ Date: 01/19/18 Time: 20:41 } \\
\hline \multicolumn{5}{|c|}{ Sample: 19702016} \\
\hline \multicolumn{5}{|c|}{ Included observations: 42} \\
\hline \multicolumn{5}{|c|}{ Cointegrating form } \\
\hline Variable & Coefficient & Std. error & t-Statistic & Prob. \\
\hline D (LAFAY_INDEX $(-1))$ & 1.405002 & 0.346213 & 4.058204 & 0.0012 \\
\hline D (LOG_DVPT_ASS) & 2.501586 & 2.203217 & 1.135424 & 0.2753 \\
\hline D (LOG_DVPT_ASS $(-1)$ ) & -0.999750 & 2.142857 & -0.466550 & 0.6480 \\
\hline D (LOG_DVPT_ASS $(-2)$ ) & 6.852759 & 1.707993 & 4.012169 & 0.0013 \\
\hline D (LOG_DVPT_ASS $(-3)$ ) & 5.377336 & 1.855227 & 2.898479 & 0.0117 \\
\hline D (LOG_FDI_INFLOW) & -0.774124 & 0.498158 & -1.553973 & 0.1425 \\
\hline D (LOG_FDI_INFLOW $(-1)$ ) & -0.214468 & 0.374172 & -0.573180 & 0.5756 \\
\hline D (LOG_FDI_INFLOW $(-2)$ ) & 0.676900 & 0.442465 & 1.529837 & 0.1483 \\
\hline D (LOG_FDI_INFLOW $(-3)$ ) & 0.511473 & 0.223753 & 2.285886 & 0.0384 \\
\hline D (LOG_GDP_CAP) & 5.093924 & 6.059788 & 0.840611 & 0.4147 \\
\hline D (LOG_GDP_CAP $(-1)$ ) & -11.463544 & 6.726872 & -1.704142 & 0.1104 \\
\hline D (LOG_GDP_CAP $(-2)$ ) & -3.291511 & 6.644939 & -0.495341 & 0.6280 \\
\hline D (LOG_GDP_CAP $(-3)$ ) & 11.556599 & 5.354352 & 2.158356 & 0.0488 \\
\hline D (LOG_MILK_CATTLE) & -13.229005 & 3.225018 & -4.101994 & 0.0011 \\
\hline D (LOG_MILK_CATTLE $(-1)$ ) & 10.346097 & 3.510971 & 2.946791 & 0.0106 \\
\hline D (LOG_MILK_CATTLE $(-2)$ ) & -3.434072 & 2.812778 & -1.220883 & 0.2423 \\
\hline D (TRADE_OPEN) & -0.063797 & 0.067714 & -0.942159 & 0.3621 \\
\hline D (TRADE_OPEN $(-1))$ & -0.189687 & 0.060370 & -3.142065 & 0.0072 \\
\hline D (TRADE_OPEN $(-2))$ & -0.072023 & 0.069839 & -1.031263 & 0.3199 \\
\hline @DURING (“1994”) & 0.985069 & 7.456168 & 0.132115 & 0.8968 \\
\hline D (@TREND ()) & 1.381514 & 0.316357 & 4.366943 & 0.0006 \\
\hline CointEq $(-1)$ & -3.228565 & 0.551287 & -5.856411 & 0.0000 \\
\hline $\begin{array}{r}\text { Cointeq }=\text { LAFAY_INDEX - } \\
+2.6225^{*} \text { LOG_GDP_CAP } \\
+0.3051 * @ \text { DU }\end{array}$ & $\begin{array}{l}-2.2016^{*} \mathrm{LO} \\
9.2230^{*} \mathrm{LOC} \\
\mathrm{NG} \text { ("1994”) }\end{array}$ & $\begin{array}{l}\text { DVPT_ASS } \\
\text { IILK_CATT } \\
26.6043+0\end{array}$ & $\begin{array}{l}12 * \text { LOG_FD } \\
0.0729 * \text { TRA } \\
* \text { @TREND) }\end{array}$ & $\begin{array}{l}\text { FLOW } \\
\text { OPEN }\end{array}$ \\
\hline
\end{tabular}


Table 6. Long run coefficients.

\begin{tabular}{ccccc}
\hline Variable & Coefficient & Std. error & t-Statistic & Prob. \\
\hline LOG_DVPT_ASS & -2.201633 & 0.635956 & -3.461928 & 0.0038 \\
LOG_FDI_INFLOW & -0.381239 & 0.211024 & -1.806615 & 0.0924 \\
LOG_GDP_CAP & 2.622472 & 1.429192 & 1.834934 & 0.0878 \\
LOG_MILK_CATTLE & -9.222966 & 1.141177 & -8.081976 & 0.0000 \\
TRADE_OPEN & 0.072868 & 0.021899 & 3.327518 & 0.0050 \\
@DURING (“1994”) & 0.305111 & 2.303736 & 0.132442 & 0.8965 \\
C & 126.604319 & 18.423888 & 6.871748 & 0.0000 \\
@TREND & 0.427903 & 0.043057 & 9.938115 & 0.0000 \\
\hline
\end{tabular}

The results also reveal that there is no significance influence of FDI inflow to competitiveness of the dairy cluster industry; this is probably due to the fact that this cluster and the agriculture as a whole are not yet considered attractive to foreign investors.

The results show that GDP per capita has a positive long run relationship with competitiveness; however, this relationship is short of significance. This reveals that the domestic demand has not yet reached a high level of sophistication due to the country's low income status.

The results reveal that milk cattle head count has a negative and significant relationship with the competitiveness of the dairy cluster industry. This confirms our argument that the cattle head count does not contribute to competitiveness of the dairy cluster industry.

The results reveal that trade openness has a positive and significant relationship with the competitiveness of the dairy cluster industry; this is consistence with our argument that import of capital goods can increase the competitiveness and productivity of the dairy cluster industry.

Finally, the results shows no significant effect of the tragic event of 1994 on the industry, this is probably due to the fact that it lasted a short period of time and was followed by massive return of Rwandans with their cattle from neighboring countries which compensated the loss incurred during that period.

\section{Conclusions and Recommendations}

The dairy industry cluster in Rwanda is spread across the whole county, this is in line with Porter [58] defined boundaries which, according to him, can range from a single city or state to a country or even a group of neighboring countries; this allows the cluster to utilize resources across the country to the benefit of the dairy industry, this includes market, cattle, infrastructures, related and supporting industries. Our study has identified a number of competitive advantages in the dairy cluster which took place in response to challenges facing the dairy industry in Rwanda. 
This study also argues that some factors have been wrongly identified as competitive advantage of the dairy industry, this includes the large number of farmers involved in cattle rearing due to cattle farming association coupled with government programs such as "One cow per poor family" program. Our study suggests that this should not be considered as a competitive advantage but rather, it adds pressure on the already scarce land [12] and other production factors. In contrast to Porter's diamond paradigm which puts emphasis on the home-based diamond, this study follows other previous studies by suggesting that home-based diamond alone cannot convey competitiveness to the dairy industry cluster of Rwanda especially with breakthrough recorded in communication and technology as well as increasing regional integration which makes countries virtually borderless. In this regard, this study proposed a multiple-diamond model which extends the diamond model to include other factors central to the competitiveness of the dairy industry cluster in Rwanda; this includes the role of FDI, international trade, human mobility, as well as the role of NGOs and development partners. To test the effect of the proposed multiple-diamond determinants on the competitiveness of the dairy cluster industry in Rwanda, ARDL test was ran. The findings confirmed the effect of trade on the dairy cluster industry competitiveness. Development assistance and milk cattle were found to have a negative and significant effect on the dairy cluster industry competitiveness. Finally, the test results reveal that FDI inflow and market sophistication were found to have insignificant effect on the dairy cluster industry competitiveness.

This study would like to put forth the following recommendations:

1) Partners in development assistance with Rwanda should urge the government to scale up its investment in the area; this would make a significant impact on the improvement of the competitiveness, and increase its attractiveness toward foreign investors.

2) This study would like to suggest the government to switch, move their emphasis from increase in cattle head count through government program such as "one cow per power family" to other strategies aimed at improving efficiency and productivity. This would help to avoid an increase of unprofessional farmers who contribute to inefficiency and low productivity in this area and amount to a significant misallocation of resources. The resources used in these types of schemes could instead be reallocated to other activities with significant impact on the industry's productivity and competitiveness such as infrastructures, research activities such as bovine genetic improvement and innovative solutions to tackle the feed shortage.

3) Given the significant impact of trade on competitiveness, the government should put more emphasis on any activities designed to promote and further liberalize trade. In this regard, we hail the government steps to promote the regional integration as crucial to improvement and upgrading of domestic competitiveness. 


\section{Limitation and Directions for Future Research}

The fact that studies on what prompts farmers to opt from government-sponsored scheme such as one cow per poor family are not available constitutes a major limitation for this study. Moreover, the availability of data on human movement across borders and inability to factor the culture of Rwanda in the model also constituted a hindrance to the achievement of this study's purpose. Consideration of these two factors by including them in the model would shed further light on the determinants of competitiveness of the domestic diamond in general and that of dairy cluster industry in particular. Another limitation was the inability to capture policy influence in our model.

Future studies should put more emphasis on investigating the challenges faced by farmers especially those who take part in the government sponsored-schemes; also, future research in this area should make attempt to identify proxies for culture, people movement as well as policy in order to assess their effect on competitiveness the dairy cluster industry.

\section{References}

[1] FAO (2018) Rawanda at a Glance. http://www.fao.org/rwanda/fao-in-rwanda/rwanda-at-a-glance/en/

[2] World Bank (2013) Agricultural Development in Rwanda. http://www.worldbank.org/en/results/2013/01/23/agricultural-development-in-rwa $\underline{\text { nda }}$

[3] Karenzi, E., et al. (2013) Kivuguto Traditional Fermented Milk and the Dairy Industry in Rwanda, A Review. Biotechnology, Agronomy, Society and Environment (BASE), 17, 383-391.

[4] JLIFAD (2016) Rwanda Dairy Development Project (RDDP).

[5] Adekunle, J. (2007) Culture and Customs of Rwanda. Greenwood Publishing Group, Santa Barbara, California.

[6] Onesme, N. (2016) Government Programs in Transforming Lives of Rwandans. A Case Study of Girinka Munyarwanda Program in Gicumbi District. Imperial Journal of Interdisciplinary Research, 2, 1387-1394.

[7] MINAGRI (2013) Rwanda National Dairy Strategy.

[8] Ezeanya, C. (2014) Indigenous Knowledge, Economic Empowerment and Entrepreneurship in Rwanda: The Girinka Approach. Journal of Pan African Studies, 6, 241-263.

[9] Militery Ngamata, O., Mbonyinkebe, D. and Lebailly, P. (2013) Social Economic Resilience of Poor Households in Rwanda: VUP 2020 and Girinka Program. Tropentag 2013 Agricultural Development within the Rural-Urban Continuum: Book of Abstracts. 29.

[10] Abdulsamad, A. and Gereffi, G. (2016) East Africa Dairy Value Chains.

[11] Klapwijk, C., et al. (2014) The "One Cow Per Poor Family" Programme: Current and Potential Fodder Availability within Smallholder Farming Systems in Southwest Rwanda. Agricultural Systems, 131, 11-22. https://doi.org/10.1016/j.agsy.2014.07.005

[12] Mutimura, M., et al. (2013) Status of Animal Feed Resources in Rwanda. Tropical 
Grasslands-Forrajes Tropicales, 1, 109-110. https://doi.org/10.17138/TGFT(1)109-110

[13] Umuzigambeho, J.F. (2017) Gender Assessment of Dairy Value Chains: Evidence from Rwanda. FAO, Rome.

[14] Porter, M.E. (1998) Clusters and the New Economics of Competition. Harvard Business Review, 76, 77-99.

[15] Porter, M.E. (1990) The Competitive Advantage of Nations. Harvard Business Review, 68, 73-93.

[16] Cho, D.-S., Moon, H.-C. and Kim, M.-Y. (2009) Does One Size Fit All? A Dual Double Diamond Approach to Country-Specific Advantages. Asian Business \& Management, 8, 83-102. https://doi.org/10.1057/abm.2008.27

[17] Jin, B. and Moon, H.-C. (2006) The Diamond Approach to the Competitiveness of Korea's Apparel Industry: Michael Porter and beyond. Journal of Fashion Marketing and Management. An International Journal, 10, 195-208.

https://doi.org/10.1108/13612020610667504

[18] Riasi, A. (2015) Competitive Advantages of Shadow Banking Industry: An Analysis Using Porter Diamond Model. Business Management and Strategy, 6, 15-27. https://doi.org/10.5296/bms.v6i2.8334

[19] Chaabna, S. and Wang, H. (2015) Analysis of the State of E-Commerce in Algeria. International Journal of Marketing Studies, 7, 44. https://doi.org/10.5539/ijms.v7n2p44

[20] Aghdaie, S.F.A., Seidi, M. and Riasi, A. (2012) Identifying the Barriers to Iran's Saffron Export by Using Porter's Diamond Model. International Journal of Marketing Studies, 4, 129.

[21] Mann, M. and Byun, S.-E. (2011) Accessing Opportunities in Apparel Retail Sectors in India: Porter's Diamond Approach. Journal of Fashion Marketing and Management: An International Journal, 15, 194-210. https://doi.org/10.1108/13612021111132636

[22] Dunning, J.H. (2003) The Role of Foreign Direct Investment in Upgrading China's Competitiveness. Journal of International Business and Economy, 4, 1-13.

[23] Dunning, J.H. (1993) Internationalizing Porter's Diamond. MIR: Management International Review, 7-15.

[24] Rugman, A.M. (1992) Porter Takes the Wrong Turn. Business Quarterly, 56, 59-64.

[25] Chang Moon, H., Rugman, A.M. and Verbeke, A. (1995) The Generalized Double Diamond Approach to International Competitiveness, in beyond the Diamond. Emerald Group Publishing Limited, Bingley, West Yorkshire, 97-114.

[26] Cho, D.-S. (1994) A Dynamic Approach to International Competitiveness: The Case of Korea. Asia Pacific Business Review, 1, 17-36. https://doi.org/10.1080/13602389400000002

[27] Cho, D.-S. and Moon, H.-C. (2000) From Adam Smith to Michael Porter: Evolution of Competitiveness Theory. World Scientific, Singapore, Vol. 2. https://doi.org/10.1142/4531

[28] Rugman, A.M. and D'cruz, J.R. (1993) The Double Diamond Model of International Competitiveness: The Canadian Experience. MIR: Management International Review, 17-39.

[29] Moon, H.C., Rugman, A.M. and Verbeke, A. (1998) A Generalized Double Diamond Approach to the Global Competitiveness of Korea and Singapore. International Business Review, 7, 135-150. https://doi.org/10.1016/S0969-5931(98)00002-X 
[30] Cho, D.-S., Moon, H.-C. and Kim, M.-Y. (2008) Characterizing International Competitiveness in International Business Research: A MASI Approach to National Competitiveness. Research in International Business and Finance, 22, 175-192. https://doi.org/10.1016/j.ribaf.2007.04.002

[31] Cartwright, W.R. (1993) Multiple Linked Diamonds and the International Competitiveness of Export-Dependent Industries: The New Zealand Experience. MIR: Management International Review, 55-70.

[32] O’Malley, E. and Van Egeraat, C. (2000) Industry Clusters and Irish Indigenous Manufacturing: Limits of the Porter View. Economic and Social Review, 31, 55-79.

[33] Rugman, A.M. and Verbeke, A. (1993) Foreign Subsidiaries and Multinational Strategic Management: An Extension and Correction of Porter's Single Diamond Framework. MIR: Management International Review, 71-84.

[34] UNCTAD (2017) Urban Population as Percentage of Total Population.

[35] UNCTAD (2005) Gross Domestic Product: Total and Per Capita, Current and Constant Prices, Annual, 1970-2016, 2017.

[36] Bloom, N., Draca, M. and Van Reenen, J. (2016) Trade Induced Technical Change? The Impact of Chinese Imports on Innovation, IT and Productivity. The Review of Economic Studies, 83, 87-117. https://doi.org/10.1093/restud/rdv039

[37] Ali, M., Cantner, U. and Roy, I. (2016) Knowledge Spillovers through FDI and Trade: The Moderating Role of Quality-Adjusted Human Capital. Journal of Evolutionary Economics, 26, 837-868. https://doi.org/10.1007/s00191-016-0462-8

[38] Blomstrom, M. and Kokko, A. (1998) Multinational Corporations and Spillovers. Journal of Economic Surveys, 12, 247-277. https://doi.org/10.1111/1467-6419.00056

[39] Blomström, M., Kokko, A. and Mucchielli, J.-L. (2003) The Economics of Foreign Direct Investment Incentives. In: Herrmann, H. and Lipsey, R., Eds., Foreign Direct Investment in the Real and Financial Sector of Industrial Countries, Springer, Berlin, 37-60. https://doi.org/10.1007/978-3-540-24736-4_3

[40] Borensztein, E., De Gregorio, J. and Lee, J.W. (1998) How Does Foreign Direct Investment Affect Economic Growth? Journal of International Economics, 45, 115-135. https://doi.org/10.1016/S0022-1996(97)00033-0

[41] Moosa, I.A. and Cardak, B.A. (2006) The Determinants of Foreign Direct Investment: An Extreme Bounds Analysis. Journal of Multinational Financial Management, 16, 199-211. https://doi.org/10.1016/j.mulfin.2005.07.002

[42] Moosa, I. (2002) Foreign Direct Investment: Theory, Evidence and Practice. Springer, Berlin. https://doi.org/10.1057/9781403907493

[43] Lipsey, R.E., et al. (1999) The Role of Foreign Direct Investment in International Capital Flows, in International Capital Flows. University of Chicago Press, Chicago, 307-362.

[44] Romer, P. (1990) Endogenous Technological Change. Journal of Political Economy, 98, S71-S102. https://doi.org/10.1086/261725

[45] Aghion, P., et al. (1998) Endogenous Growth Theory. MIT Press, Cambridge, Massachusetts.

[46] Sanchezrobles, B. and Bengoacalvo, M. (2003) Foreign Direct Investment as a Source of Endogenous Growth. SSRN Electronic Journal, $20 \mathrm{p}$.

https://doi.org/10.2139/ssrn.410441

[47] Li, X. and Liu, X. (2005) Foreign Direct Investment and Economic Growth: An Increasingly Endogenous Relationship. World Development, 33, 393-407. https://doi.org/10.1016/j.worlddev.2004.11.001 
[48] Grossman, G.M. and Helpman, E. (1993) Innovation and Growth in the Global Economy. MIT Press, Cambridge, Massachusetts.

[49] Kwok, C.C. and Tadesse, S. (2006) The MNC as an Agent of Change for Host-Country Institutions: FDI and Corruption. Journal of International Business Studies, 37, 767-785. https://doi.org/10.1057/palgrave.jibs.8400228

[50] UNCTAD (1992) Transnational Corporations as Engines of Growth, in World Investment Report, United Nations Conference on Trade, New York.

[51] Antoine, M.M. (2018) Moderating Role of FDI Spillovers: Evidence from China. International Journal of Research in Business Studies and Management, 5, 29-37. https://doi.org/10.3386/w5048

[52] Coe, D.T., Helpman, E. and Hoffmaister, A. (1995) North-South R \& D Spillovers. National Bureau of Economic Research.

[53] Ekanayake, E. and Chatrna, D. (2010) The Effect of Foreign Aid on Economic Growth in Developing Countries. Journal of International Business and Cultural Studies, 3, 1.

[54] Durbarry, R., Gemmell, N. and Greenaway, D. (1998) New Evidence on the Impact of Foreign Aid on Economic Growth. CREDIT Research Paper.

[55] Morrissey, O. (2001) Does Aid Increase Growth? Progress in Development Studies, 1, 37-50. https://doi.org/10.1177/146499340100100104

[56] Bingi, S. and Tondel, F. (2015) Recent Developments in the Dairy Sector in Eastern Africa. European Centre for Development Policy Management, Briefing Note, 78.

[57] MININFRA (2017) National Feeder Roads Policy and Strategy. Rwanda Ministry of Infrastructure.

[58] Porter, M.E. (2000) Location, Competition, and Economic Development. Economic Development Quarterly, 14, 15-34. https://doi.org/10.1177/089124240001400105

[59] Makoni, N., et al. (2014) White Gold: Opportunities for Dairy Sector Development Collaboration in East Africa. Centre for Development Innovation, Wageningen UR.

[60] Keller, W. (2010) International Trade, Foreign Direct Investment, and Technology Spillovers. Handbook of the Economics of Innovation, 2, 793-829.

https://doi.org/10.1016/S0169-7218(10)02003-4

[61] Madsen, J.B. (2007) Technology Spillover through Trade and TFP Convergence: 135 Years of Evidence for the OECD Countries. Journal of International Economics, 72, 464-480. https://doi.org/10.1016/j.jinteco.2006.12.001

[62] Coe, D.T. and Helpman, E. (1995) International R \& D Spillovers. European Economic Review, 39, 859-887. https://doi.org/10.1016/0014-2921(94)00100-E

[63] Xu, B. and Wang, J. (1999) Capital Goods Trade and R \& D Spillovers in the OECD. Canadian Journal of Economics, 32, 1258-1274. https://doi.org/10.2307/136481

[64] Filatotchev, I., et al. (2011) Knowledge Spillovers through Human Mobility across National Borders: Evidence from Zhongguancun Science Park in China. Research Policy, 40, 453-462. https://doi.org/10.1016/j.respol.2011.01.003

[65] Lokuruka, M.N. (2016) Overview of Dairy Processing and Marketing in East African Dairy Value Chains: Opportunities and Challenges. African Journal of Food Science, 10, 254-262. https://doi.org/10.5897/AJFS2016.1465

[66] NISR (2016) Statistical Year Book.

[67] NISR (2015) Rwanda Poverty Profile Report (2013-2014).

[68] Land O'Lakes, Rwanda Dairy Competitiveness Program II (RDCP II) Impact Report, 2017, Land O'Lakes. 
[69] Hill, R.C., Griffiths, W.E. and Lim, G.C. (2008) Principles of Econometrics. Vol. 5, Wiley Hoboken, NJ.

[70] Piotr, S. and Krzysztof, H. (2016) Competitive Position of the Dairy Sector's Foreign Trade in the EU. In ISER 42nd International Conference, World Research Library, Zurich, Switzerland. 